\title{
The Multidimensional Phenomenon of Study Success in Higher Education-A Head Start to Success at Work?
}

\author{
Satu Uusiautti (Corresponding author) \\ University of Lapland \\ PO Box 122, 96100 Rovaniemi, Finland
}

Tel: 358-40-484-4150Ｅ-mail: Satu.Uusiautti@ulapland.fi

\author{
Kaarina Määttä \\ University of Lapland \\ PO Box 122, 96100 Rovaniemi, Finland \\ Tel: 358-400-696-480Ｅ-mail: Kaarina.Maatta@ulapland.fi
}

\author{
Received: May 22, 2016 Accepted: June 7, 2016 Published: August 1, 2016 \\ doi:10.5296/jse.v6i3.9540 URL: http://dx.doi.org/10.5296/jse.v6i3.9540
}

\begin{abstract}
Universities are worried about students' satisfaction and well-being. These elements are important when pursuing to enhance efficient graduation and quality outcomes in studies. The changing world, indeed, has changed the elements of success in education and in work, too, which is the area of life students enter from universities. The purpose of this article is, first, to discuss the prerequisites of study success in universities, and second, to establish a connection between the phenomena of success in studies and success at work. The viewpoint leans of positive psychology. Students themselves were asked to describe success in their studies. How do students themselves perceive their study processes and what do they think about the factors that promote their success in studies. The research questions were: (1) what have been the most pleasing study experiences the students have encountered in university studies?; and (2) what factors have enhanced their study progress and success according to their own perceptions? Students $(\mathrm{N}=186)$ answered to an internet-based open-ended questionnaire. The data were analyzed in a data-based manner which resulted in eight most frequently mentioned success factor in the questionnaire data. The findings showed that there are some similarities between the phenomenon of success in studies and at work. The phenomenon is illustrated as the conclusion, and the finding can be used when developing
\end{abstract}


university education to better meet the demands of the modern, changing world of work.

Keywords: university study process, study success, study satisfaction, well-being, success at work, achievement. 


\section{Introduction}

Studying is students' work, they say. How to be satisfied with or even successful in this kind of work, is the main question of this study. Our purpose is to discuss how successful study progress and satisfaction with studies may be compared to the phenomenon of success and whether similar features of success determine the phenomenon in various areas of life.

The rapidly changing modern society necessitates that new ways of securing students' satisfaction with their studies have to be discovered (Välijärvi et al., 2007). This is important if we want to prepare them to cope with the whirlpool of modern work (Bailey, 2014; Cascio, 2013), too, and to succeed in their future careers (Uusiautti \& Määttä, 2015). New studies, such as the one conducted by Mari Salmela about Finnish straight-A graduates (Salmela, 2016), point out that traditional education emphasizes usually strengths related to critical thinking, pursuit of excellence, diligence, and high academic achievements, while it seems that other kinds of strengths might be more wanted in the world of work students enter after studies (Peterson, Stephens, Park, Lee, \& Seligman, 2013).

However, studying is also a long-term process. This means that success does not necessarily mean just the straight As at the end, but also it is reasonable to pay attention to all that happens before achieving the successful measurable study goals. There are many studies available that have focused on describing teaching arrangements that enhance smooth study processes in higher education (Biggs, 2001; Määttä \& Uusiautti, 2012; Määttä, Uusiautti, \& Määttä, 2016; Samarawickrema \& Stacey, 2007). This study contributes to the discussion the student viewpoint: how do students themselves describe the elements of their study success?

\section{Theoretical Background}

How to define success? Often, study satisfaction refers to elements that increase students' contentment with their study progress and smoothness of their study paths. They usually cover features of functional study environment (e.g., library services, ICT support, classrooms, etc.), professional teaching personnel, and quality study structures (e.g., well-designed curricula, grading and evaluation systems) (Garrison \& Kanuka, 2004; Lenning \& Ebbers, 1999; Salmela et al., 2015). Students' satisfaction with their studies is boosted if they can plan studies autonomously and have abundantly options of how, what, and when to study (Lizzio, Wilson, \& Simons, 2002). Actually, these features represent merely the study environment and conditions, which are important but just one dimension of an actual successful study process (Määttä et al., 2016).

Here, our purpose is to compare study success with the theory of success at work (Uusiautti, 2016). Success as a concept ignites some contradictory feelings: on the one hand, it is something desirable and worth-pursuing, and on the other hand, it has negative connotations related to power, opportunism, and cold-heartedness. Our perspective is positive. According to it, success can consist of expertise, competence, and successes that come from intrinsic motivation and interest in one's doing, and thus success can be seen as a positive inner feeling of oneself (Uusiautti, 2008; 2015; Uusiautti \& Määttä, 2015).

This positive state is multi-dimensional. When someone becomes riveted and senses the 
greatest self-fulfillment, he or she can achieve the state of flow (Csikszentmihalyi, 2008), and engagement and joy (Hakanen, Perhoniemi, \&Toppinen-Tanner, 2008; Mesurado, Richaud, \& Mateo, 2015; Stairs \&Galpin, 2013). Actually, freedom to choose - in other words, autonomy - enhances capability to act, which can create the flow state so that accomplishing becomes possible, which again contributes to the sense of meaning in doing. This can be called as the positive circle of intrinsic motivation (Järvilehto, 2013; Martela \& Jarenko, 2014; Määttä, 2015), which can raise the student's motivation from disinterest and the so-called shortcut-seeking toward achievement motivation and genuine interest in learning and gaining profound knowledge in the field (Männikkö \& Pohjatalo, 2015; Määttä, 2015; Salmela \& Uusiautti, 2015).

The way we have outlined the phenomenon of success from a person's personal perspective can also be connected to other concepts that are closely related to positive manifestation of human development and agency (Brown Kirschman, Johnson, Bender, \& Roberts, 2009; Magnusson \& Mahoney, 2003; Maddux, 2002; Uusiautti \& Määttä, 2015). One of them is the concept of positive psychological capital (Youssef \& Luthans, 2013) that is gained during studies can support succeeding when entering the world of work as well (Uusiautti \& Määttä, 2013). This "PsyCap" consists of efficacy, hope, optimism, and resiliency and is used for explaining positive organizational behavior and development. As such, it still does not refer to success, but it complements our understanding about the positive phenomenon of success.

According to our previous studies (Uusiautti \& Määttä, 2015; Uusiautti, 2016), success at work appeared a complex network of high performance, intrinsic motivation, drive and engagement, and development and competence. They are interesting from the viewpoint of success in studies as well. Previously, Uusiautti defined the concept of a worker's personal success at work as the combination of three elements (Uusiautti, 2013) that were (1) certain individual features (such as competence, motivation, ability to select positive strategies) and on the context-bound features (such as opportunities and restrictions, expectations, and obligations); (2) positively-focused proactivity at work (such as seizing opportunities, employing one's strengths, and pursuing personal development); and (3) a sense of meaningful doing, productivity, and perceived well-being at work. In sum, the positive experience of work is one of the most essential dimensions of success (Liden, Wayne, \& Sparrowe, 2000).

However, when analyzing the phenomenon of success not just as an individual person's actions and characteristics, it becomes evident how the outer conditions and interpersonal relationships influence the process of success too (Uusiautti, 2015; 2016). All these are interconnected-conditions, social relationships, and personal factors. The conclusion was that when the process is good, positive action and phenomena occur too, leading to the success as (measurable) outcomes (Uusiautti, 2015; 2016). Would it be possible to analyze study success similarly?

\section{Method}


The main question was to know what factors make studying and study progress smooth and lead to successful outcomes according to students' perceptions, and to define study success from this perspective.

The following research questions were set for this study:

(1) What have been the most pleasing study experiences the students have encountered in university studies? and

(2) What factors have enhanced their study progress and success according to their own perceptions?

Students from the University of Lapland were selected as research participants. The data collection happened via an Internet-based questionnaire called "Webropol". This questionnaire was used for obtaining information about students' study experiences so that their concerns could be better noticed when planning teaching and education at the university. Therefore, the questionnaire served a general purpose. The questionnaire included open-ended questions prompting students to write about their most pleasing experiences during studies, their prerequisites and hindrances of success, etc.

The questionnaire was sent to 506 students who had registered as present students for their first study year at the University of Lapland. Of them, 186 replied. The questionnaire was sent May 6, 2014 and a reminder note May 13, 2014 was sent to those who had not replied. The due date for participation in the research was May 20, 2014. The participation rate was $36.8 \%$ which was considered sufficient for the purposes of this study. The timing of the study at the end of the study year might have influence on the participation because in May already many students return their home places across Finland or start their summer jobs, and thus are not actively involved in studies.

Those who participated in the study were mostly women: $74 \%$ were women and $23 \%$ men ( $3 \%$ of students, $n=5$, did not report their genders). The distribution resembles the actual distribution of women and men at the University of Lapland. Of the participants of this study, $67 \%$ were under 24 years old; $18 \%$ were $25-29$ years old; $4 \%$ were $30-34$ years old; and $6 \%$ were over 40 years old. The median of students at the University of Lapland is 27 years.

The participants of this study also represented the four faculties (= departments) of the university relatively well. 44 students $(23.7 \%)$ were from the faculty of education, 49 students $(26.3 \%)$ were from the faculty of law, 27 students $(15.5 \%)$ were from the faculty of arts, and 66 students $(35.5 \%)$ were from the faculty of social sciences.

The University of Lapland is the northernmost university of the European Union. It is a small university with about 5,000 students. Even though small university enables open and easy interaction between students and the teaching staff, university studies are still demanding. In order to be able to develop teaching further, it is important to listen to students' experiences. Therefore, a qualitative research approach was chosen in this study. Due to the high number of students, an open-ended questionnaire was considered the best method to address students and reach their perceptions and experiences (Denscombe, 2008). Even though loss was 
relatively high, the number of participants and quality of data were still considered satisfactory for the purposes of the research. As the objective was to give voice to students themselves, the main emphasis in the data collection was to receive descriptions rich in contents and variety. In this sense, the method served well the study.

The data were analyzed with a content analysis method that was qualitative data-based analysis (Kolbe \& Burnett, 1991). First, the students' responses were categorized into rough categories that formed the initial division into items describing their perceptions of study success and factors enhancing it. Then, the analysis continued with a more specific categorization into categories that would include items that resembled similar theme (such as positive atmosphere or experienced successes). Eventually, eight main categories could be distinguished that outlined the main factors the students mentioned when describing their study success.

When it comes to reliability in studies like this one, some basic issues can be evaluated. First, the reliability of the data collection method must be assessed. In this study, the internet-based questionnaire was considered the most suitable way of contacting students: they could be easily reached via email. Another advantage was that they could fill the questionnaire whenever the most convenient for them. However, this always causes some disadvantages too: many respondents may easily forget or ignore the request to participate in the research, or answers can remain short and superficial. In addition, the researcher cannot be certain who has actually answered the questions (although it is highly unlikely that someone else could answer in behalf of a student) and how, for example, the circumstances of the answering moment (e.g., mood, motivation, satisfaction of studies or latest courses, or other factors in students' personal lives) have influenced the students' answers. The quality of research is, therefore, mainly based on the quality of data, in this case the contents of answers (Couper, Kapteyn, Schonlau, \& Winter, 2007).

In addition, the reliability of this study was pursued to strengthen with collaboration of two researchers (Wray, Markovic, \& Manderson, 2007). This enhanced the analysis by making sure that interpretations were not just based on one person's preconceptions but on data. Yet, it is still possible that some other researcher or research group could categorize or interpret the data differently. However, for the purposes of the study, the analysis showed that it was possible to define study success in this theory-led manner even though the categories emerged from the data.

\section{Results}

Students' descriptions of their positive study experiences and success were categorized into eight categories.

The most important element of success was the experiences of successes. They increased students' study satisfaction and contentment. Successes were reported to boost one's sense of efficacy and capability. Especially, passing a demanding exam after studying hard provided a benign positive experience. Many of the students mentioned that passing the very first exam at the university was a memorable event. Indeed, the meaning of the good start whether it was 
in studies, at school in general or in a new workplace, should never be underestimated (see e.g., Keup \& Barefoot, 2005; Schellenberg \& Bailis, 2015). The students described their positive experiences as follows:

"Passing the first exam"

Studying and reading numerous books require dedication and persistence, but when good grades are achieved, motivation increases and studying provides joy. Good grades and surpassing one's own expectations were also mentioned as factors of boosting success. Smooth study progress was described as an especially pleasant study experience.

"To handle a difficult course well."

"When the first exam went better than I expected"

Successes are a mark of right kinds of study skills and ability to adjust in the academic study environment. Therefore, it is important to become familiar with one's strengths and weaknesses as a student as well as oneself as a learner (Gonzáles, Jareno, \& Lopez, 2015).

The students also acknowledged good relationships with other students as an important success factor. More often than not, students have to move to a new place to study, leave home and old friends behind. Finding new friends among peer students help engagement to studies and the study place, and function as a social resource during the student life (Vaarala, Uusiautti, \& Määttä, 2013).

"New friends are worth their weight in gold."

Working together makes studying meaningful (FitzSimmons, 2014). According to the data, the sense of belonging to a group and acceptance form a source of encouragement. Peer support and advice from older students were also perceived meaningful for successful study progress (see also Hamer, Purchase, Luxton-Reilly, \& Denny, 2015; Ludemann \& McMakin, 2014; Topping, 1998; Wierstra, Kanselaar, Van Der Linden, \& Lodeewijks, 1999).

"The absolutely best positive experience during this study year has been the people of my own study group and the fact how well I get along with them all."

"Creating the excellent group spirit in our home group; studying is nice in a good team."

Students also described the wider study environment and emphasized the importance of an open atmosphere at the university. According to their experiences, the smallness of their university made it easy to approach teachers and professors, and most of them hand found interaction with them immediate and relaxed. Positive and encouraging atmosphere were therefore named as one element in successful study processes. They had noted that not only positive relationships between students but also teaching personnel were valuable.

“The small size of the university increases communality."

"The overall atmosphere is nice and relaxed between students and teachers. It is nice that you can ask teachers help." 
Indeed, the students seemed to connect the positive atmosphere (see also Shahidi \& Sobhani, 2015) with the opportunity of asking help and being helped when needed. Actually, it has been noted that prompt, timely help and support (instead of keeping students dwelling with their concerns) make an important condition of timely graduation (Cortes, Mostert, \&Els, 2014). If students feel that their worries are nullified, that they do not dare to bother the teaching personnel with their questions, or that they are ignored, even the smallest issues that could be solved easily can accumulate into big problems and lead to prolonged studies and even dropping out (Cortes et al., 2014; Määttä, 2016; Olwage \& Mostert, 2014; Stratton, O’Toole, \& Wetzel 2008).

Teaching and teachers' dedication and enthusiasm were perceived inspiring and motivating. The students appreciated teachers who invested in their teaching methods and styles, and contents of their lectures. Teachers and courses that were the most pleasing to them were mentioned by name in the data.

"To get the exact information from the course that you were looking for. Interesting teachers who put their soul into teaching make lectures interesting even if the theme wasn't"

"Also, the group communication course was interesting and especially nice, and the teacher was competent."

"Interesting themes"

Face-to-face teaching was appreciated in the data, but students also noticed those teachers who used varied teaching methods. They had enjoyed the variety and had also perceived that more often than not, different methods provided an opportunity to study faster.

"The teaching personnel consists of very nice and warm people. I have been able to study online which has suited me well."

Students in the data emphasized that studies and studying itself were rewarding. Learning new and recognizing development in themselves had been exciting and even surprising. Especially the aforementioned variety in study methods had showed their strengths and resources, and strengthened their belief in their abilities. When studying itself becomes a motivating factor, instead of just achievements and measurable goals, we can talk about intrinsic motivation (Vansteenkiste, Lens, \& Deci, 2006).

"Studying itself has been rewarding, after my years at work."

"Learning new things."

"It has been great to notice new sides in myself. For example, I didn't consider myself very profound or apt to academic thinking previously but courses that have gone well and positive feedback have improved my self-esteem and I feel like the university is the right place to me."

"Studying just for yourself has been lovely. I feel like having come to a place where I can study in way that is meaningful to me. My experience is that I have been able to express myself and that I have been appreciated." 
Activities in studies and practical training or practicums as well as connections to work life were highlighted in the data as good experiences. Various small group tasks and seminars were reported as pleasing study methods. Practical training related to one's field increased motivation and enthusiasm.

"The first practicum and group lessons."

"All those courses that have allowed me to do things in practice, e.g., graphical technology and software courses. Learning has been concrete during those courses and I have noticed my development clearly."

"One singular experience is 'Leadership and organization' course which had those strategic development workgroups that were challenging but rewarding and inspiring to perform. Studying felt relevant and comparable to methods used in actual work. Thinking about skills needed at work, the course was apparently beneficial, to develop those skills."

"Practically-oriented courses, such as 'Conciliation' and 'The witness's support'. They gave me more than ordinary literature exams.”

As the studies went on, many students had become convinced that their own field of studies or their major had increased their satisfaction in their studies. Their choice had proved to be right when they had noticed that their field had started to interest them increasingly. It had met their expectations and they felt that they wanted to develop as experts in their own field. This is also about finding a field that corresponds one's strengths. Being able to use one's signature strengths and developing in their direction can become the most valuable source of well-being in life (Van Niekerk, Mostert, \& de Beer, 2016)-making also studies seem especially meaningful.

"Studies in my own field have been the most rewarding."

"The most pleasing thing has been when I realized that this is it, this is what I want to do."

When talking about study satisfaction and success, many students mentioned that they wanted to schedule their studies in a way that suits them best. Indeed, flexibility in teaching arrangements and study schedules were frequently mentioned success factors. Various optional ways of performing studies, for example writing essays instead of literature exam, were mentioned as factors that speed up studies. Variety and optional tasks were considered beneficial. Different teaching arrangements, such as online lectures and self-scheduled exams in the so-called computer-based exam class, brought much appreciated flexibility in studies.

“Good opportunities to perform studies by writing essays.”

"Self-scheduled exams, online exams, and online courses make planning your own schedule effortless."

Flexible timetables and opportunities to online participation in lectures make studying easier. Freedom, autonomy, and self-directed studies were reported as positive experience and as a dimension that they had not learned until entering the university. Flexibility was also appreciated by those students who worked alongside studies as well as by those who had 
children and had to arrange child care during their studies.

"The best thing has been to notice how flexible studying is. The courses has lasted three weeks at the most, while most of them have been one- or two-week-long spurts. Due to flexible schedules, I have been able to spend a lot of time in my home city and work alongside studies."

"The most pleasant study experiences have been related to participatory teaching methods and flexible practices."

The last main category found in the data covered the active and positive feedback given by teachers. Personal comments and individual feedback were regarded as support and encouragement. Students reported that the constructive feedback about their performances in essays, exams, or other tasks helped them find the right direction in their studies. They also received information about their development, strengths, and ways to perform various tasks.

"I have received personal comments and feedback about my work."

"The sense of development and feedback from teachers."

"Some courses have been especially high-quality, and I have learned good practical skills that have developed my expression. - - In these courses, teachers have been ready to give advice and guide, due to which these courses have given me so much.”

"The teacher who evaluated provided plenty of constructive feedback, and inspired and encouraged me..."

\section{Discussion}

The purpose of this article was to describe how students themselves perceive their study success. The results showed what the most important success factors were as described by them. As we wanted to compare the findings with the earlier theorization of the phenomenon of success, we placed the findings in Figure 1 that illustrates how the findings represent study success not only as good grades and graduations but also as fluent and pleasant study processes in which well-being and positivity exist. 


\section{1) Macrothink}

Journal of Studies in Education

ISSN 2162-6952

2016, Vol. 6, No. 3

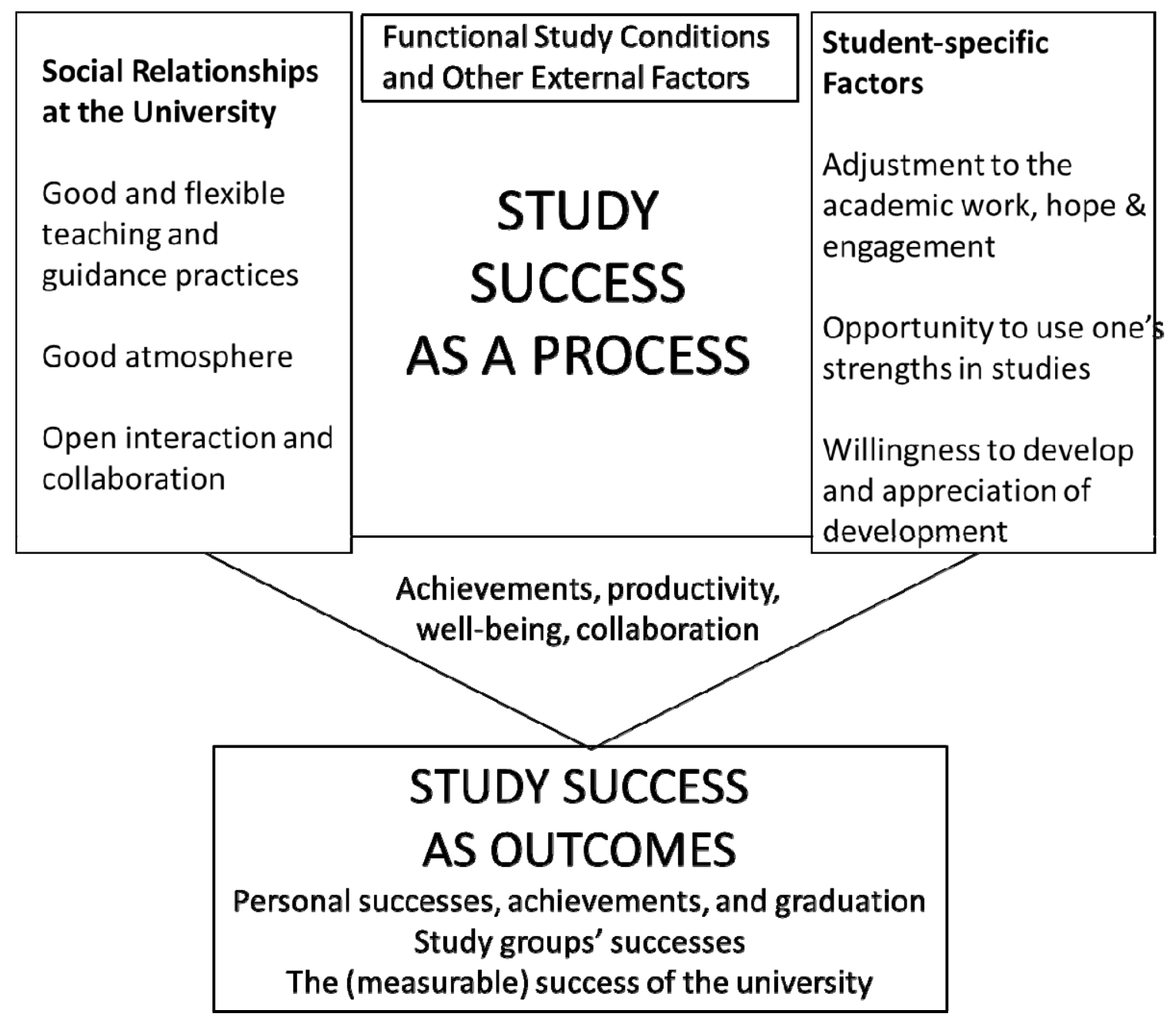

Figure 1. Study success as a process and outcomes (retelling Uusiautti 2015, p. 133; 2016)

On the one hand, students referred to flexible teaching arrangements and well-designed courses, and positive, encouraging interaction between the teaching personnel and peer students. They also appreciated prompt guidance practices and the sense of being appreciated. These items are represented in Figure 1 as social relationships at the university. Peer relationships, friendships, and pleasant encounters with teachers and professors (Bowman \& Akcaoglu, 2014; Määttä, 2015; Symonds, 2014) make an important success factor especially when talking about study success as a process.

The students also mentioned variety of study methods (e.g., online lectures and exams) and other outer factors. Although they were not considered the main success factors, they have a crucial role in the successful study process as well. In all, functional study environment lays the basic foundation of success.

In the right-hand-side of Figure 1, we have placed items that describe the students' own role in the successful study process. As the students' descriptions showed, they found those situations in which they could recognize their development, find and use their strengths, and 
succeed well the most rewarding and the most important for their success. For a great part, it is a matter of attitude they take in studies: whether they can cope with the new, changing study environment, new expectations and obligations, and with the self-directed, free academic study schedules. If they are able to adjust to these conditions in an open-minded and noble manner, their engagement to studies is likely to be high (Williams, Childers, \& Kemp, 2013). A positive attitude also shows hope - and that is needed during demanding university studies that will include hardships and tricky situations as well. Studying is not sunshine everyday but also hard work.

However, study work will be easier if the students has the opportunity use their strengths in studies (Salmela \& Uusiautti, 2015). In this research, the students described how they had gained the sense of being in the right place, studying the right field. In these cases, we may interpret that they have found the field that suits their strengths the best. This can lead to not only maximal performances (Mitchell, 1997; see also Howell, 2009) but also to the greatest self-fulfillment and well-being in life (Ouweneel, Le Blanc, \& Schaufeli, 2011).

Finally, success includes the element of development. Some students in the data pointed out how they perceived their development as a part of their study success. When development becomes the goal, students show profound intrinsic motivation to become experts in their field - this feature described also Finnish top workers extremely well (see Uusiautti \& Määttä, 2015). Likewise, Vansteenkiste et al. (2006) argue that intrinsic goal framing related to intrinsic motivation "produces deeper engagement in learning activities, better conceptual learning, and higher persistence at learning activities" (p. 19).

The aforementioned factors summarized the study success as a process. However, when it comes to success, the element of achievements, including those measurable ones, have a distinct role. Study success as outcomes refers to smooth study progress, high grades in courses, and timely graduation. That is the goal at which the majority of students aim. And actually, achieving as such has been regarded as one of the five important elements of well-being in human beings (Seligman, 2011; Uusiautti, Määttä, \& Leskisenoja, 2016). At the same time, study success as outcomes can manifest itself as the study group's productive work and fruitful collaboration. From the university's point of view, study success as outcomes is seen as efficient teaching, high number of study points performed each semester, and, eventually, fast-graduating students. That is plainly one of the most important measurable goals of universities (Bunce, Baird, \& Jones, 2016).

The figure illustrates how the positive process goes hand in hand with the favorable outcomes. True study success is about both of them: well-being in students, teaching personnel, and the academic community tells about the success of study processes (Uusiautti \& Määttä, 2016). This kind of "happiness advantage" (Achor 2010) has been proven to lead better productivity, efficiency, and results (Bunce et al., 2016).

\section{Conclusion}

Our study suggests that students should be equipped with understanding of their own capability to reach new goals, address various challenges and opportunities (Proctor, Maltby, 
\& Linley, 2011). Study success therefore means self-reflection as well; in other words, familiarization with one's abilities, strengths, and weaknesses (Linley, Willars, \& Biswas-Diener, 2010), and using them actively and daring to lead life in their direction (Seligman, 2011).

However, to better meet the demands of the modern life, education should support strengths that improve well-being, satisfaction, and positive behaviors and citizenship (see also Salmela \& Uusiautti, 2015), in other words, learning of how to be well and succeed in life. Such strengths are, for example, gratitude, thoughtfulness, compassion, and team work (Park \& Peterson, 2009; Popov, 1997). There is an increasing understanding that these kinds of strengths contribute to social relationships and to the sense of meaning and well-being (Park \& Peterson, 2009), and are increasingly needed and appreciated in today's world of work, too. This is how study success at its best may contribute to these students' future as workers. Therefore, an important question is: can success in studies lead to success at work?

When considering positive development from the point of view of success in studies, it becomes crucial to recognize factors that enhance success in a way that boosts positive self-image, awareness of one's strengths, and optimistic attitude (Beard, Humberstone, \& Clayton, 2014; Rowe, Fitness, Wood, 2015). Experiences and events taking place in childhood, adolescence, and early adulthood can be crucial, or at least, direct and maintain people in a right direction in adulthood and later life (Gottfried, Fleming, \& Gottfried, 2001; Magnusson \& Mahoney, 2003). However, positive development is a holistic process of an individual person, in which also the cultural, physical, and historical context matters. The main point is how well the person can seize the opportunities or cope with the challenges their context provides. Therefore, the findings can be compared with several earlier studies on the importance of positive feedback, constructive evaluation, and good relationships at the university. At their best, they improve students' initiation and activity in their studies as well as their ability to detect their core strengths and evaluate their own learning and study skills (Boud \& Molloy, 2013; Carless, Salter, Yang, \& Lam, 2011).

The study also showed that the students not only appreciate but actually need endlessly feedback (West \& Turner, 2015) in order to develop as students, learners, and members of an academic community (Winstone, Nash, Rowntree, \& Parker, 2016). In addition to the support of the university community as a whole, all this is greatly based on positive attitudes toward studies and tasks, study community and peers. Adopting a positive and optimistic attitude increases resilience during demanding university studies. The successes in studies that follow are likely to support the positive attitude and create a sense of self-efficacy that is not easily shaken by possible adversities (Maddux, 2002). It exemplifies also the positive psychological capital of knowing "who I am" (Luthans, Luthans, \& Luthans, 2004). Success in studies when understood from the perspective represented in this article may, at least, enhance or improve students' chances of finding success at work, too, because they possess the invaluable knowledge of themselves as learners and workers, and have gained the inner zeal to develop as an experts in their chosen field that they are now studying and in which they will be working in the future. 


\section{References}

Achor, S. (2010). The happiness advantage. The seven principles of positive psychology that fuel successes and performance at work. New York, NY: Crown Business.

Bailey, T. (2014). Changes in the nature of work: Implications and skills for assessment. In H. F. O’Neill Jr. (Ed.), Workforce readiness. Competencies and assessment (pp. 27-46). New York, NY: Psychology Press.

Beard, C., Humberstone, B., \& Clayton, B. (2014). Positive emotions: passionate scholarship and student transformation. Teaching in Higher Education, 19(6), 630-643. http://dx.doi.org/10.1080/13562517.2014.901950

Biggs, J. (2001). The reflective institution: Assuring and enhancing the quality of teaching and learning. Higher Education, 41(3), 221-238. http://dx.doi.org/10.1023/A:1004181331049

Brown Kirschman, K. J., Johnson, R. J., Bender, J. A., \& Roberts, M. C. (2009). Positive psychology for children and adolescents: Development, prevention, and promotion. In S. J. Lopez \& C. R. Snyder (Eds.), Oxford handbook of positive psychology (pp. 133-148). Oxford: Oxford University Press.

Boud, D., \& Molloy, E. (2013). Rethinking models of feedback for learning: the challenge of design. Assessment \& Evaluation in Higher Education, 38(6), 698-712. http://dx.doi.org/10.1080/02602938.2012.691462

Bowman, N. D., \& Akcaoglu, M. (2014). “I see smart people!”: Using Facebook to supplement cognitive and affective learning in the university mass lecture. The Internet and Higher Education, 23, 1-8.

Bunce, L., Baird, A., \& Jones, S. E. (2016). The student-as-consumer approach in higher education and its effects on academic performance. Studies in Higher Education, online. http://dx.doi.org/10.1080/03075079.2015.1127908

Carless, D., Salter, D., Yang, M., \& Lam, J. (2011). Developing sustainable feedback practices. Studies in Higher Education, 36(4), 395-407. http://dx.doi.org/10.1080/03075071003642449

Cascio, W. F. (2013). The changing world of work. In P. A. Linley, S. Harrington, \& N. Garcea (Eds.), The Oxford handbook of positive psychology and work (pp. 13-24). Oxford: Oxford University Press.

Cortes, K., Mostert, K., \& Els, C. (2014). Examining significant predictors of students' intention to drop out. Journal of Psychology in Africa, 24(2), 179-185. http://dx.doi.org/10.1080/14330237.2014.903070

Couper, M. P., Kapteyn, A., Schonlau, M., \& Winter, J. (2007). Noncoverage and nonresponse in an Internet survey. Social Science Research, 36(1), 131-148. http://dx.doi.org/10.1016/j.ssresearch.2005.10.002

Csikszentmihalyi, M. (2008). Finding flow: The psychology of engagement with everydaylife. 
New York, NY: Basic Books.

Denscombe, M. (2008). The length of responses to open-ended questions. A comparison of online and paper questionnaires in terms of a mode effect. Social Science Computer Review, 26(3), 359-368. http://dx.doi.org/10.1177/0894439307309671

FitzSimmons, R. (2014). On the importance of collaborative peer learning as a collective learning experience in Finnish higher education classrooms. Critical Education, 5(16), 1-17.

Garrison, D. R., \& Kanuka, H. (2004). Blended learning: Uncovering its transformative potential in higher education. Internet and Higher Education, 7, 95-105. http://dx.doi.org/10.1016/j.iheduc.2004.02.001

González, M. D. L. O., Jareño, F., \& López, R. (2015). Impact of students' behavior on continuous assessment in Higher Education. Innovation: The European Journal of Social Science Research, 28(4), 498-507.

Gottfried, A. E., Fleming, J. S., \& Gottfried, A. W. (2001). Continuity of academic intrinsic motivation from childhood through late adolescence: A longitudinal study. Journal of Educational Psychology, 93(1), 3-13. http://dx.doi.org/10.1037/0022-0663.93.1.3

Hakanen J., Perhoniemi R., \& Toppinen-Tanner S. (2008). Positive gain spirals at work: from job resources to work engagement, personal initiative and work-unit innovativeness. Journal of Vocational Behavior, 73, 78-91. http://dx.doi.org/10.1016/j.jvb.2008.01.003

Hamer, J., Purchase, H., Luxton-Reilly, A., \& Denny, P. (2015). A comparison of peer and tutor feedback. Assessment \& Evaluation in Higher Education, 40(1), 151-164. http://dx.doi.org/10.1080/02602938.2014.893418

Howell, A. J. (2009). Flourishing: Achievement-related correlates of students' well-being. The Journal of Positive Psychology, 4(1), 1-13. http://dx.doi.org/10.1080/17439760802043459

Järvilehto, L. (2013). Upeaatyötä! [Great work!]. Helsinki: Tammi.

Keup, J., \& Barefoot, B. (2005). Learning how to be a successful student: Exploring the impact of first-year seminars on student outcomes. Journal of The First-Year Experience \& Students in Transition, 17(1), 11-47.

Kolbe, R. H., \& Burnett, M. S. (1991). Content-analysis research: an examination of applications with directives for improving research reliability and objectivity. Journal of Consumer Research, 18(2), 243-250.

Lenning, O. T., \& Ebbers, L. H. (1999). The powerful potential of learning communities: Improving Education for the Future. ASHE-ERIC Higher Education Report, 26(6). Washington, DC: The George Washington University. Retrieved from: http://files.eric.ed.gov/fulltext/ED428606.pdf

Liden, R. C., Wayne, S. J. \& Sparrowe, R. T. 2000. An examination of the mediating role of psychological empowerment on the relations between the job, interpersonal relationships, and 
work outcomes. Journal of Applied Psychology, 85(3), 407-416.

Linley, A., Willars, J., \& Biswas-Diener, R. (2010). The strengths book. Be confident, be successful, and enjoy better relationships by realizing the best of you. Coventry: CAPP Press.

Lizzio, A., Wilson, K., \& Simons, R. (2002). University students' perceptions of the learning environment and academic outcomes: implications for theory and practice. Studies in Higher Education, 27(1), 27-52. http://dx.doi.org/10.1080/03075070120099359

Ludemann, P. M., \& McMakin, D. (2014). Perceived helpfulness of peer editing activities: first-year students' views and writing performance outcomes. Psychology Learning \& Teaching, 13(2), 129-136. http://dx.doi.org/10.2304/plat.2014.13.2.129

Luthans, F., Luthans, K. W., \& Luthans, B. C. (2004). Positive psychological capital: Beyond human and social capital. Business Horizons, 47, 45-50.

Maddux, J. E. (2002). Self-efficacy. The power of believing you can. In C. R. Snyder \& S. J. Lopez (Eds.), Handbook of positive psychology (pp. 277-287). Oxford: Oxford University Press.

Magnusson, D., \& Mahoney, J. L. (2003). A holistic person approach for research on positive development. In L. G. Aspinwall \& U. M. Staudinger (Eds.), A psychology of human strengths (pp. 227-244). Washington, DC: Apa.

Martela, F., \& Jarenko, K. (2014). Sisäinen motivation. Tulevaisuuden työssä tuottavuus ja innostus kohtaavat [Intrinsic motivation. In the future work, productivity and enthusiasm encounter]. Helsinki: Lahden tutkimus- ja koulutuskeskus.

Mesurado, B., Richaud, M. C., \& Mateo, N. J. (2015). Engagement, flow, self-efficacy, and eustress of university students: a cross-national comparison between the Philippines and Argentina. The Journal of Psychology, 150(3), 1-24. http://dx.doi.org/10.1080/00223980.2015.1024595

Mitchell, T. R. (1997). Matching motivational strategies with organizational contexts. Research in Organizational Behavior, 19, 57-149.

Männikkö, L., \& Pohjatalo, A. (2015). Opiskelumotivaatio [Study motivation]. OK-opintokeskus. Retrieved from: http://kouluttaja.ok-opintokeskus.fi/opiskelumotivaatio.

Määttä, K. (2015). Mistä puhutaan kun puhutaan opettamisesta Lapin yliopistossa? Kahviokeskustelun virtaa [What do we talk about when we talk about teaching at the University of Lapland? Flow of cafeteria discussion]. Rovaniemi: University of Lapland.

Määttä, K. (2016). A caring supervisor. In S. Uusiautti \& K. Määttä (Eds.), The basics of caring research (pp. 79-90). Rotterdam: Sense Publishers.

Määttä, K., \& Uusiautti, S. (2012) How to enhance the smoothness of university students' study paths. International Journal of Research Studies in Education, 1(1), 47-60. http://dx.doi.org/105861/ijrse.2012.v1i1.16 
Määttä, K., Uusiautti, S., \& Määttä, M. (2016). A story of an ideal study process. In S. Uusiautti \& K. Määttä (Eds.), The basics of caring research (pp. 91-102). Rotterdam: Sense Publishers.

Olwage, D., \& Mostert, K. (2014). Predictors of student burnout and engagement among university students. Journal of Psychology in Africa, 24(4), 342-350. http://dx.doi.org/10.1080/14330237.2014.978087

Ouweneel, E., Le Blanc, P. M., \& Schaufeli, W. B. (2011). Flourishing students: A longitudinal study on positive emotions, personal resources, and study engagement. The $\begin{array}{llll}\text { Journal of Positive } & \text { Psychology, } & 6(2), & \text { 142-153. }\end{array}$ http://dx.doi.org/10.1080/17439760.2011.558847

Park, N., \& Peterson, C. (2009). Strengths of character in schools. In R. Gilman, E. S.Huebner, \& M. J. Furlong (Eds.), Handbook of positive psychology in schools (pp. 65-76). New York, NY: Routledge.

Peterson, C., Stephens, J. P., Park, N., Lee, F., \& Seligman, M. E. P. (2013). Strengths of character and work. In P. A. Linley, S. Harrington, \& N. Garcea (Eds.), The Oxford handbook of positive psychology and work (pp. 221-234). Oxford: Oxford University Press.

Proctor, C., Maltby, J., \& Linley, P. A. (2011). Strengths use as a predictor of well-being and health-related quality of life. Journal of Happiness Studies, 12, 153-169. http://dx.doi.org/10.1007/s10902-009-9181-2

Popov, K. L. (1997). The family virtues guide. Simple ways to bring out the best in ourchildren and ourselves. New York, NY: Penguin Group.

Rowe, A. D., Fitness, J., \& Wood, L. N. (2015). University student and lecturer perceptions of positive emotions in learning. International Journal of Qualitative Studies in Education, 28(1), 1-20. http://dx.doi.org/10.1080/09518398.2013.847506

Salmela, M. (2016). Tie ylioppilastutkinnon huippuarvosanoihin laudaturylioppilaiden kertomana [Paths to the highest scores in the Finnish Matriculation Examination as described by straight-A graduates]. (PhD Diss., University of Lapland, Rovaniemi, Finland.)

Salmela, M., \& Uusiautti, S. (2015). A positive psychological viewpoint for success at school -Ten characteristic strengths of the Finnish high-achieving students. High Ability Studies, 26(1), 117-137. http://dx.doi.org/10.1080/13598139.2015.1019607

Salmela, M., Uusiautti, S., \& Määttä, K. (2015). Finnish high-achieving students' perceptions ofthe best practices in teaching. International Journal of Education, 7(2), 126-145.

Samarawickrema, G., \& Stacey, E. (2007). Adopting web - based learning and teaching: a case study in higher education. Distance Education, 28(3), 313-333. http://dx.doi.org/10.1080/01587910701611344

Schellenberg, B. J., \&Bailis, D. S. (2015). Predicting longitudinal trajectories of academic passion in first-year university students. Learning and Individual Differences, 40, 149-155. 
http://dx.doi.org/10.1016/j.lindif.2015.04.008

Seligman, M. E. P. (2011). Flourish. A visionary new understanding of happiness and well-being. New York, NY: FreePress.

Shahidi, M., \& Sobhani, A. (2015). Psycho-educational problems in large academic classes: learning motivation within psycho-educational atmosphere.Academic Research International, $6(1), 322$.

Stairs, M., \& Galpin, M. (2013). Positive engagement: From employee engagement to workplace happiness. In P. A. Linley, S. Harrington \& N. Garcea (Eds.), The Oxford handbook of positive psychology and work (pp. 155-172). Oxford: Oxford University Press.

Stratton, L. S., O’Toole, D. M., \& Wetzel, J. N. (2008). A multinomial logit model of college stopout and dropout behavior. Economics of Education Review, 27(3), 319-331. http://dx.doi.org/10.1016/j.econedurev.2007.04.003

Symonds, M. R. (2014). Lecturing and other face-to-face teaching-too much or too little? An assessment based on student feedback and fail rates. Higher Education Research \& Development, 33(6), 1221-1231. http://dx.doi.org/10.1080/07294360.2014.911256

Topping, K. (1998). Peer assessment between students in colleges and universities. Review of Educational Research, 68(3), 249-276. http://dx.doi.org/10.1177/1469787414527391

Uusiautti, S. (2008). "Tänään teen elämäni parhaan työn.” Työmenestys Vuoden Työntekijöiden kertomana. ["Today, I'll work better than ever." Employees of the year describe their experiences of success at work.] (PhD Diss., University of Lapland, Rovaniemi, Finland.)

Uusiautti, S. (2013). On the positive connection between success and happiness. International Journal of Research Studies in Psychology, 3(1), 1-11. http://dx.doi.org/10.5861/ijrsp.2013.509

Uusiautti, S. (2015). Menestyvä ja hyvinvoiva yritys positiivisen psykologian valossa. Yritysjohdon ja työntekijöiden näkemyksiä menestyksestä [Successful and thriving enterprise in the light of positive psychology. Leaders' and employees' perceptions of success] Helsinki: BoD.

Uusiautti, S. (2016). Success at work requires hope and the ability to engage in an optimistic attitude. European Journal of Workplace Innovation, in press.

Uusiautti, S., \& Määttä, K. (2013). Enhancing student' study success through caring leadership. European Scientific Journal, 2(2), 398-407.

Uusiautti, S., \& Määttä, K. (2015). The psychology of becoming a successful worker: Research on the changing nature of achievement at work. New York, NY: Routledge.

Uusiautti, S., \& Määttä, K. (2016). Caring research and its future challenges. In S. Uusiautti \& K. Määttä (Eds.), The basics of caring research (pp. 137-144). Rotterdam: Sense Publishers. 
Uusiautti, S., Määttä, K., \& Leskisenoja, E. (2016). Why is success at work important? A case study in a midsized Finnish enterprise. Journal for International Business and Entrepreneurship Development, in press.

Vaarala, M., Uusiautti, S., \& Määttä, K. (2013). College students' experiences of and coping withloneliness - Possibilities of peer support. International Journal of Research Studies inEducation, 2, 13-28. http://dx.doi.org/10.5861/ijrse.2013.510

Van Niekerk, G., Mostert, K., \& de Beer, L. T. (2016). Strengths use and deficit improvement: The relationship with engagement and fit with study course amongst first-year students. Journal of Psychology in Africa, 1-6.

Vansteenkiste, M., Lens, W., \& Deci, E. L. (2006). Intrinsic versus extrinsic goal contents in self-determination theory: another look at the quality of academic motivation. Educational Psychologist, 41(1), 19-31. http://dx.doi.org/10.1207/s15326985ep4101_4

Välijärvi, J., Kupari, P., Linnakylä, P., Reinikainen, P., Sulkunen, S., Törnroos, J., \& Arffman, I. (2007). The Finnish success in PISA - And some reasons behind it 2. PISA 2003. Jyväskylä: Institute for Educational Research.

West, J., \& Turner, W. (2015). Enhancing the assessment experience: improving student perceptions, engagement and understanding using online video feedback. Innovations in Education and Teaching International, online 21 Jan 2015. http://dx.doi.org/10.1080/14703297.2014.1003954

Wierstra, R. F., Kanselaar, G., Van Der Linden, J. L., \& Lodeewijks, H. G. (1999). Learning environment perceptions of European university students. Learning Environments Research, 2(1), 79-98.

Williams, K. H., Childers, C., \& Kemp, E. (2013). Stimulating and enhancing student learning through positive emotions. Journal of Teaching in Travel \& Tourism, 13(3), 209-227. http://dx.doi.org/10.1080/15313220.2013.813320

Winstone, N. E., Nash, R. A., Rowntree, J., \& Parker, M. (2016). "It'd be useful, but I wouldn't use it": barriers to university students' feedback seeking and recipience. Assessment \& Evaluation in Higher Education, online 20 Aug 2015. http://dx.doi.org/10.1080/02602938.2015.1075956

Wray, N., Markovic, M., \& Manderson, L. (2007). "Researcher saturation": The impact of data triangulation and intensive-research practices on the researcher and qualitative research process. Qualitative Health Research, 17(10), 1392-1402. http://dx.doi.rog/10.1177/1049732307308308

Youssef, C. M., \& Luthans, F. (2013). An integrated model of psychological capital in the workplace. In P. A. Linley, S. Harrington, \& N. Garcea (Eds.), The Oxford handbook of positive psychology and work (pp. 277-288). Oxford: Oxford University Press. 


\section{Copyright Disclaimer}

Copyright for this article is retained by the author(s), with first publication rights granted to the journal.

This is an open-access article distributed under the terms and conditions of the Creative Commons Attribution license (http://creativecommons.org/licenses/by/3.0/). 